\title{
The region that isn't: China, Russia and the failure of regional integration in Central Asia
}

\author{
Sebastian Krapohl ${ }^{1}$ (D) Alexandra Vasileva-Dienes ${ }^{1,2}$
}

Received: 21 January 2019 /Revised: 30 April 2019 /Accepted: 1 May 2019 /

Published online: 28 May 2019

(C) The Author(s) 2019

\begin{abstract}
The failure of regionalism in Central Asia is a puzzle. Whereas almost all world regions have seen a rise of regional organisations since the end of the Cold War, attempts to establish durable regional cooperation among Kazakhstan, Kyrgyzstan, Tajikistan, Turkmenistan and Uzbekistan proofed unsuccessful. Although some of the Central Asian countries participate in wider regional organisations like the Eurasian Economic Union (EAEU) and the Shanghai Cooperation Organisation (SCO), the genuine Central Asian Cooperation Organisation (CACO) was dissolved in 2005. Given the cultural, economic and political similarities between the five Central Asian countries, this lack of a regional organisation is surprising. In contrast to previous work, this paper argues that the failure of regionalism in Central Asia is not so much due to domestic political factors, but more to the extra-regional economic dependence of the regional economies and the impact of external powers within Central Asia. Challenged by the rise of China, Russia uses the EAEU in order to preserve its hegemonic influence over the former Soviet Republics. By joining the Russian dominated EAEU, Central Asia's regional power Kazakhstan enjoys economic benefits which outweigh the potential gains of Central Asian cooperation within CACO by far. Consequently, Kazakhstan follows its extra-regional interests in closer cooperation with Russia at the cost of regional cooperation with its Central Asian neighbours. As a result, the Central Asian countries are unable to build up a unified regional block in relation to extra-regional powers like China or Russia.
\end{abstract}

Sebastian Krapohl

s.krapohl@uva.nl

Alexandra Vasileva-Dienes

alexandra.dienes@fes-vienna.org

1 Faculty of Social and Behavioural Sciences, University of Amsterdam, Nieuwe Achtergracht 166, 1018 WV Amsterdam, Netherlands

2 Friedrich-Ebert-Stiftung (FES), Regional Office for Cooperation and Peace in Europe (ROCPE), Reichsratsstraße 13/5, 1010 Vienna, Austria 


\section{Introduction}

The five 'Stans' of Central Asia_Kazakhstan, Kyrgyzstan, Tajikistan, Turkmenistan and Uzbekistan - are clearly recognisable as a region, whose member states have more in common with each other than with external neighbours. The five countries share a moderate Islam as majority religion, they all look back on a common history as former Soviet republics under Russian dominance, and they are currently all governed by (semi-)authoritarian presidents. Nevertheless, whereas the spread of the new regionalism since the 1990s has led to the emergence of regional organisations in almost all world regions (Mansfield and Milner 1999), a genuine Central Asian integration project does not exist. The Central Asian Cooperation Organisation (CACO) was dissolved in 2005, and Kazakhstan and Kyrgyzstan joined the Russian-dominated Eurasian Economic Community (EurAsEC) and later the Eurasian Economic Union (EAEU) (Bohr 2004; Pomfret 2009). Thus, two of the five Central Asian countries participate in some form of regionalism today, but Central Asia as such is nevertheless one of the very few world regions which has not managed to establish a regional organisation on its own.

The comparative regionalism literature deals extensively with the emergence of regional organisations all around the world since the 1990s (Mansfield and Milner 1999), but it has not yet explored under which circumstances regions fail to establish regional organisations. Scholars usually analyse prominent regional organisations like the Association of Southeast Asian Nations (ASEAN), the Common Market of South America (MERCOSUR) or the Southern African Development Community (SADC) (Krapohl 2017a), which exist since several decades and are relatively stable. Thus, we know that the new regionalism has been a reaction to globalisation (Schirm 2002), and that successful integration of one world region triggers integration in other world regions (Mattli 1999), but we do not know under which circumstances these forces reach their limits and regionalism collapses.

Different schools of international relations theory stress different structural factors to explain the success of regionalism. Realists argue that it needs a regional hegemon or leader, which provides a regional order on behalf of all other regional countries (Lake 2009; Mattli 1999). This poses a problem for Central Asia, where Kazakhstan and Uzbekistan rival for regional leadership. Whereas Kazakhstan is economically much stronger than Uzbekistan, the latter has a larger population and more military power. Constructivists stress the importance of a regional identity (Acharya 2005), which they deem to be necessary for regional integration. Such a common regional identity seems to be weak in Central Asia, and consequently the prospects for regionalism are poor. Finally, liberals concentrate on domestic interests within regional states in order to explain the success or failure of regional cooperation (Moravcsik 1998). In this respect, the authoritarian political structures in Kazakhstan, Kyrgyzstan, Tajikistan, Turkmenistan and Uzbekistan are problematic for regionalism, because political elites and especially the presidents avoid regional cooperation to avoid opening up their countries and losing political control (Bohr 2004; Collins 2009; Spechler 2002).

The problem is that none of these variables - neither hegemony, nor regional identity, nor authoritarian political systems - is able to explain the complex pattern of success or failure of regionalism in different world regions. MERCOSUR in South America and SADC in Southern Africa are both dominated by regional hegemons, but Brazil and South Africa have not always provided the necessary leadership and 
damaged regionalism with unilateral actions (Krapohl et al. 2014). A regional identity is slowly emerging in ASEAN (Acharya 2005), but it is unclear why this happens in a culturally diverse region as Southeast Asia and not in a culturally more homogeneous region like Central Asia. Finally, authoritarian-ruled countries like Myanmar or Zimbabwe participate in regional organisations like ASEAN or SADC, and Kazakhstan and Kyrgyzstan themselves are members of the EAEU (Roberts and Moshes 2016). Thus, authoritarianism alone does not necessarily prevent regionalism (Allison 2008).

We argue that the failure of regionalism in Central Asia is due to two interrelated factors: First, like in other developing regions of the global south, intraregional economic interdependence is low in Central Asia. This does not mean that there exists no demand for regional integration in Central Asia, but the demand is different to that in economically well-developed regional organisations like the Europe Union (EU). The main economic demand for European integration results from the utilisation of comparative cost advantages and economies of scale on the single market (Mattli 1999), where the EU member states trade more than $60 \%$ of their exports and imports. In contrast, the share of intraregional trade within Central Asia is only about $10 \%$ (see 'Economic dependency of Central Asia' section below). The Central Asian economies are dependent on the export of agricultural products and a few commodities like gas and oil to extra-regional markets. Thereby, they all share the fundamental infrastructure problems of landlocked countries at the periphery of the global market (Bobokulov 2006; Gleason 2001; Myant and Drahokoupil 2008). The Central Asian countries could improve their trade infrastructure and their standing on the global market considerably, if they cooperated with each other. Here, the gains of regional integration would not so much derive from intraregional economic exchange, but from an improved interaction with extra-regional actors and markets (Krapohl 2017a). Other regional organisations of the global south (for example ASEAN; Krapohl 2017b) have managed to utilise such extra-regional economic by cooperating successfully at the regional level gains (for example within the Chiang-Mai-Initiative of the ASEAN+3). However, the five Central Asian countries do not address their problems in common, but a regional organisation does not exist and the region is distinguished by high internal trade barriers.

Second, at the same time when the success of regionalism depends very much on taking a united stance in relation to extra-regional actors, Central Asia is subject of the 'Second Great Game', wherein extra-regional powers - most notably China and Russia - compete for access to Central Asia's fossil resources (Cooley 2012). Within this 'Second Great Game', Russia uses Eurasian regionalism - namely EurAsEC and later the EAEU - to restore its influence in Central Asia. For Kazakhstan, membership in EurAsEC and the EAEU guarantees safe access to the Russian market and pipeline network. This constitutes an important extra-regional economic privilege, which weights much more for Central Asia's largest economy than economic integration with its regional neighbours Kyrgyzstan, Tajikistan, Turkmenistan and Uzbekistan ever could (Collins and Bekenova 2017). Thus, Kazakhstan becomes a regional 'Rambo' (Krapohl 2017a) and prioritised its relations with Russia over regional integration in Central Asia. Because the Russian-led EAEU forms a customs union, Kazakhstan is locked into Eurasian regionalism and Central Asian regionalism becomes impossible. Thus, the 'Second Great Game' between China and Russia has torn Central Asia apart, and a genuine Central Asian regionalism could not survive.

The paper proceeds by developing the theoretical argument in 'Regionalism in the shadow of dependency' section. Here, it demonstrates how economic dependency on 
extra-regional markets influences the demand for and supply of regional cooperation in developing regions of the global south. 'The failure of regionalism in Central Asia' section analyses the emergence of Eurasian at the cost of Central Asian regionalism. It becomes visible that the Central Asian economies are highly dependent on economic exchange with China and Russia, and that the Russian strategy of Eurasian regionalism stopped the preliminary attempts of Central Asian regionalism. The conclusion summarises the findings of the empirical analysis and discusses the lessons of the Central Asian case for the academic field of comparative regionalism.

\section{Regionalism in the shadow of dependency}

The academic literature on regionalism still suffers from a divide between studies of the European Union (EU) and the field of comparative regionalism (Söderbaum and Sbragia 2011; Warleigh-Lack and Rosamond 2010). On the one hand, EU studies have developed a well-equipped theoretical toolbox in order to analyse the processes of European integration and policy-making within the EU. On the other hand, theories like liberal intergovernmentalism (Moravcsik 1998), neofunctionalism (Haas 1961) or various institutionalist approaches (Pollack 2003) are hardly applicable to cases of regionalism outside of Europe. Europe is an economically advanced region, and the regional economies profit a lot from mutual exchange on a liberalised single market. Intraregional trade makes up for $60-65 \%$ of member states' international trade (Krapohl and Fink 2013). In contrast, most other regional organisations (with the exception of the North American Free Trade Agreement, NAFTA) are composed of developing countries and emerging markets, which have much less potential to trade with each other. Thus, the share of intraregional trade in regional organisations of the global south rarely exceeds $20 \%$, and developing regions are dependent on economic exchange with other world regions. European integration theories do not account for these different economic structures, which, however, have a huge impact on regional integration.

\section{The demand for regional integration}

In order that regionalism succeeds, there needs to be demand for regional cooperation. In well-developed regions like Europe, the economic gains of regionalism result from the utilisation of comparative cost advantages and economies of scale by trading on the regional market (Mattli 1999). However, developing countries are distinguished by less diversified economies, which are dependent on the export of few commodities. The regional neighbours usually do not constitute important export markets for these goods because the regional economies are rarely compatible. Thus, the utilisation of comparative cost advantages and economies of scale generates less demand for cooperation in developing than in economically diversified regions.

Regionalism in developing world regions takes place in the shadow of extra-regional dependency. Developing countries are usually dependent on investment from and trade with more developed economies outside of their own region. Only developed economies possess the necessary capital and technology for productive investments and are able to grant significant amounts of development aid. Besides, developed economies 
constitute the main export market for primary goods, and they are the destination of labour migration which then leads to high remittance flows. Given this economic dependency, it seems that developing countries would be better off by cooperating with well-developed extra-regional partners than by setting up regional organisations together with their equally poor neighbours. Thus, the question arises, why regionalism actually exists within developing regions of the global south.

Regionalism in the global south is an instrument for developing countries to escape marginalisation on the global market (Schirm 2002). Many developing countries - maybe with the exception of Brazil, Russia, India and China (the so-called BRICs) - face the problem of being small and insignificant players on the global market and in international politics. As such, they do not constitute attractive partners for private businesses or intergovernmental cooperation. As a result, the terms of exchange will be unfavourable for them. Regionalism improves the standing of these developing countries because it bears positive size and stability effects. A regional market is necessarily bigger than each of its member states' markets on its own. Besides, regionalism improves the political stability of a region and reduces the risk of violent conflicts, because the member states of regional organisations have more peaceful means to settle their disputes (Haftel 2007). Both the size and stability effects make regions more attractive as locations for investments or as partners for international cooperation. Thus, successful regionalism constitutes a competitive advantage for the regional member states.

To sum up, the gains of regionalism in developing regions of the global south are fundamentally different from the gains of regionalism in economically advanced regions of the global north. Whereas the gains of European integration are created inside of the region, the gains of regionalism in developing regions are created by improving the regions' standing in relation to extra-regional actors. We can thus speak of the intraregional and the extra-regional logics of regionalism (Krapohl 2017a). Both rationales for regionalism exist in well-developed and developing regions, but their relative weight depends on the degrees of intraregional economic interdependence and extra-regional economic dependence.

\section{The supply of regional integration}

The fact that there exists some demand for regional cooperation in developing regions does not necessarily imply that regionalism is supplied quasi automatically (Krapohl et al. 2014; Mattli 1999). Global competition for economic gains or political influence does not stop at the regional borders, and regional member states also compete with each other. Regional cooperation may improve the standing of developing regions in international politics and on the global market, but this does not mean that all regional member states profit from it to the same degree. There need to be net benefits for all the regional countries, because single member states do not cooperate for regional gains if their individual losses exceed their share of these gains.

In a first scenario, extra-regional actors reward regional cooperation of a particular developing region systematically, and the extra-regional logic of regional cooperation is successful (Krapohl 2017a). Thus, the extra-regional relations of all regional member states improve as long as they cooperate with each other and implement regional agreements. Regional cooperation can be achieved relatively easily because every member state enjoys a net benefit. The regional member states may still disagree about 
the concrete form of regional agreements, and they may bargain about the distributive consequences of these agreements, but they all prefer cooperation over defection. In sum, the preference constellation resembles a battle-of-the-sexes, wherein coordination is not trivial, but possible (Stein 1982).

In a second scenario, extra-regional actors do not reward regional cooperation systematically but rather grant privileges to single member states of a particular developing region (Krapohl et al. 2014). These privileges may-for example - be bilateral trade agreements, access to important infrastructure or an opening up of the labour market for one particular regional member state. Such extra-regional privileges constitute an important competitive advantage for the respective developing country, but they may be at odds with regionalism. For example, bilateral trade agreements with extra-regional partners are incompatible with regional customs unions. Because of the dependency on extra-regional relations, a privileged member state of a developing region is likely to put its extra-regional interests first. The respective member state becomes a regional 'Rambo' (Holzinger 2003; Zürn 1993), which defects from regional cooperation in order to follow its extra-regional interests.

Often, it is one of the larger regional economies or even the regional power that is able to benefit from privileged extra-regional relations and that gains the least from regional integration. Regional powers are the most attractive partners within the region. This allows them to interact with extra-regional actors on more favourable terms. Besides, large regional member states profit the least from the size and stability effect of regionalism since they need to provide these goods on behalf of their smaller neighbours. In contrast to the argument of realists (Lake 2009; Mattli 1999), the dominance of one particular state usually does not have positive effects on regionalism in the global south, as regional powers put their own extra-regional interests before the common interests of the region (Krapohl et al. 2014; Krapohl 2017a). Due to their extra-regional economic dependence, they opt for privileged relations with important extra-regional actors, even if these privileges are in conflict with the goals of regional integration.

As a result of economic dependency, extra-regional actors have a huge impact on the prospects of regionalism in the global south. If extra-regional actors support regional cooperation, invest in the regional market and negotiate interregional trade and security agreements, regionalism in the global south can succeed. An example for this is ASEAN, which gained a new integration dynamic in the 2000s, because it profited a lot from extra-regional cooperation with China and Japan within the ASEAN+3 framework (Krapohl 2017b). However, if extra-regional actors grant privileges such as bilateral agreements to single member states, the chances for regional cooperation among developing countries decline. An example for this is SADC, where the bilateral Trade, Development and Cooperation Agreement (TDCA) between the EU and South Africa became a stumbling stone for deeper regional integration (Muntschick 2017). This can go to such lengths that extra-regional governments may employ a divide-and-conquer strategy in order to prevent successful regionalism. By offering significant extra-regional privileges to important regional countries, they can prevent these privileged countries from successful cooperation with their regional neighbours and hinder the development of a stronger regional organisation. 


\section{The failure of regionalism in Central Asia}

Although Central Asia was at the centre of a Eurasian trade network - the Silk Roadsin medieval times (Frankopan 2016), today it is a peripheral region in the global economy (Allison 2004). All five Central Asian countries look back on a history as Soviet republics during the Cold War. This implies that their economies enjoyed some rudimentary form of industrialisation, but also that infrastructure and trade relations were heavily oriented towards Russia (Pomfret 2009). Despite the end of the Cold War and the political independence of the five countries, the economic reliance on Russia can still be seen in current trade relations (Jenish 2015, see 'Economic dependency of Central Asia' section below for details). However, the Russian dominance is increasingly challenged by a rising China, which invests heavily in Central Asia in order to access the region's fossil fuels and other mineral reserves (Sheives 2006). Today, Central Asia and its natural resources are at the centre of a 'Second Great Game', in which China and Russia (and to a lesser extent also the EU and the USA) compete for influence (Cooley 2012; Samokhvalov 2016; von Hauff 2018). Within this 'Second Great Game', regional organisations dominated by China (i.e. the Shanghai Cooperation Organisation, SCO) and Russia (i.e. EurAsEC and later the EAEU) have become strategic instruments of power projection, and they have prevented the successful development of a genuine Central Asian regionalism (Stronski and Ng 2018; International Crisis Group 2017).

\section{Economic dependency of Central Asia}

Like in other developing regions, intraregional trade among the Central Asian countries is low, and it has been even declining since the dissolution of the Soviet Union at the beginning of the 1990s. ${ }^{2}$ In Kyrgyzstan and Tajikistan, it halved over the past 20 years, falling from 30 to $40 \%$ of total international trade in the mid-1990s to $20 \%$ in 2017 (Figs. 2 and 3). Uzbekistan does not exhibit strong regional trade links either, with the respective trade share falling from $15 \%$ in the 1990 s to $10 \%$ today (Fig. 4). Kazakhstan stands out as the least regionally integrated country, because its intraregional trade share declines from a modest $6.5 \%$ in the 1990 s to only $5 \%$ nowadays (Fig. 1).

Due to low levels of regional economic interdependence, the intraregional gains of market integration are insufficient to promote regional cooperation in Central Asia. The Central Asian countries have relatively similar commodity-dependent economies that are competing rather than complementing each other (Wang 2014). As a result, rather than developing a regional market, the Central Asian countries have repeatedly deployed protectionist measures against each other. Trade barriers such as cumbersome controls on borders persist despite the proclaimed goal of regional cooperation. This makes Central Asian states among the most difficult places in the world for cross-

\footnotetext{
${ }^{1}$ The term 'Second Great Game' refers to the first 'Great Game' of the nineteenth century, in which Russia and the UK struggled for strategic dominance in Central Asia.

${ }^{2}$ We include trade figures of Kazakhstan, Kyrgyzstan, Uzbekistan and Tajikistan. Turkmenistan is not included due to the lack of reliable trade data. Noteworthy, official trade figures likely underestimate intraregional trade since they do not include the informal 'bazaar trade', which accounts for 20-30\% of the total trade volume in Central Asia. The biggest international bazaars are the Dordoi market (Bishkek), Barakholka (Almaty), Kara-Suu (Osh) and Korvon (Dushanbe) (Wang 2014, p. 228).
} 


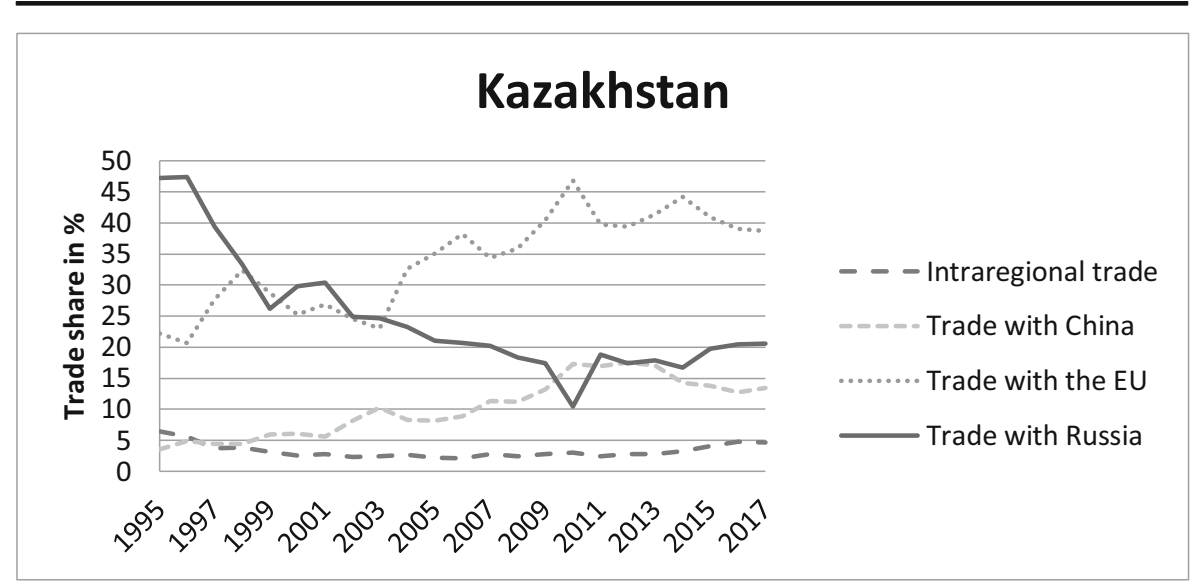

Fig. 1 Kazakhstan's International Trade. UN Comtrade database (comtrade.un.org)

border trade. For example, exporters to Kazakhstan need an average of 5 days to prepare documentation and four for custom clearance, at a total cost of around 700 USD (Russel 2019, p. 8; Doing Business 2019). Even 'informal regionalism' in the form of local trade and businesses in transboundary areas has hardly gained foothold in the region (Bohr 2004). All this has exacerbated the dependence on the extra-regional export of commodities like gas and oil.

While intraregional trade is low in Central Asia, trade dependence on external actors, foremost Russia but also increasingly China, is high. Russia has been the most important trading partner for Central Asia since the early 1990s and at least up until the financial crisis of 2008/9 (Jenish 2015). During that period Russia's trade share has increased in Kyrgyzstan (from around 20 to 35\%), Tajikistan (from 15 to 25\%) and Uzbekistan (figures fluctuate between 15 and 20\%). Cooperation with Russia is crucial for the Central Asian economies. The country has not only been a traditional market for many Central Asian goods, but it is

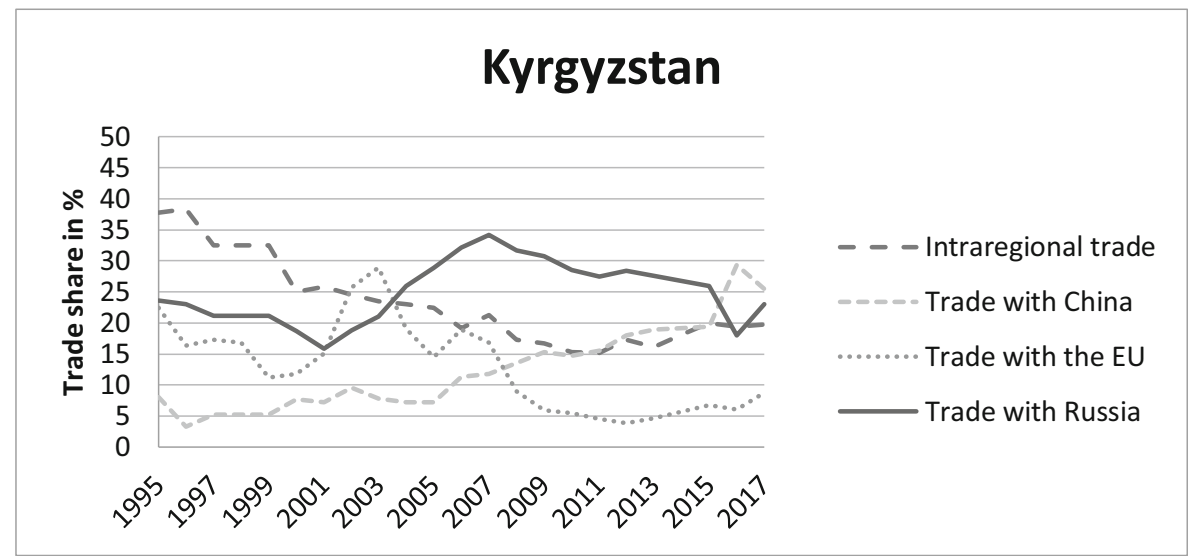

Fig. 2 Kyrgyzstan's International Trade. UN Comtrade database (comtrade.un.org). No data was available for Kyrgyz trade in 1997-1999 and in 2014. The average between figures for 1996 and 2000, as well as between figures for 2013 and 2015, were taken instead 


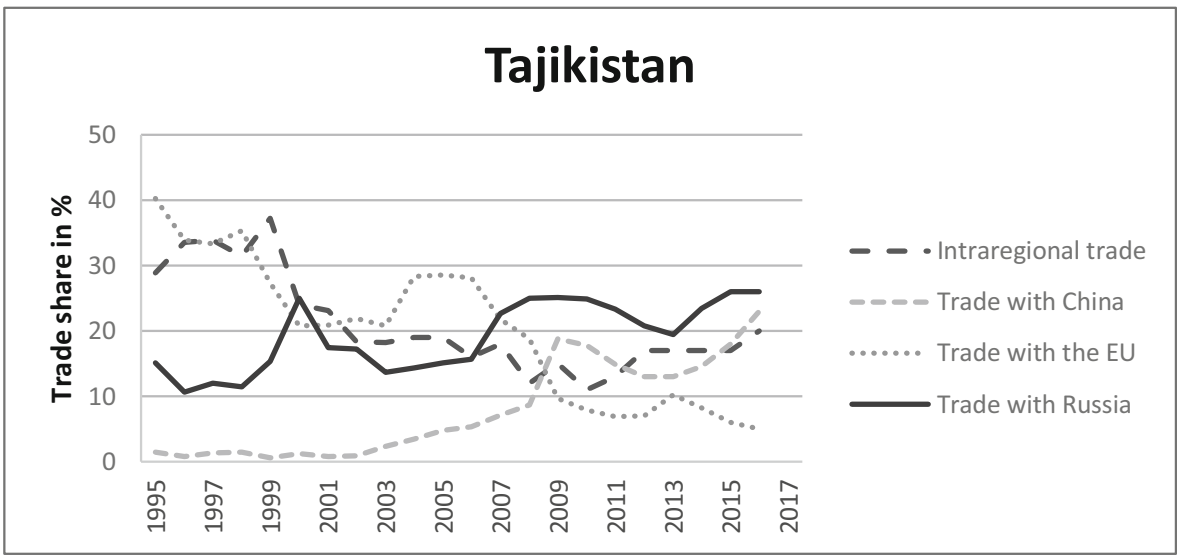

Fig. 3 Tajikistan's International Trade. Tajikistan does not report trade data to the UN. Therefore, data were obtained from the official website of the Statistical Agency of Tajikistan (www.stat.tj/ru). Missing data for trade with China, Kazakhstan and Kyrgyzstan from 1995 to 2003 were mirrored from the UN Comtrade database. No trade data were available for 2017

also the economic gateway to Europe, as $70 \%$ of Central Asian exports reach Europe through Russia. As a legacy from Soviet times, Central Asia's infrastructure is still heavily oriented north rather than connecting the five regional countries with each other (Kubicek 1997). Moreover, the countries are interested in access to Russian finances, discounted energy prices and free movement of labour, which leads to high remittances flows from emigrants (Bobokulov 2006; Spechler 2002).

China has been steadily expanding its influence in Central Asia since the 1990s (Peyrose and Raballand 2015). Until the mid-2000s, the share of trade with China was below $10 \%$ for all Central Asian countries, but it has been constantly rising since then.

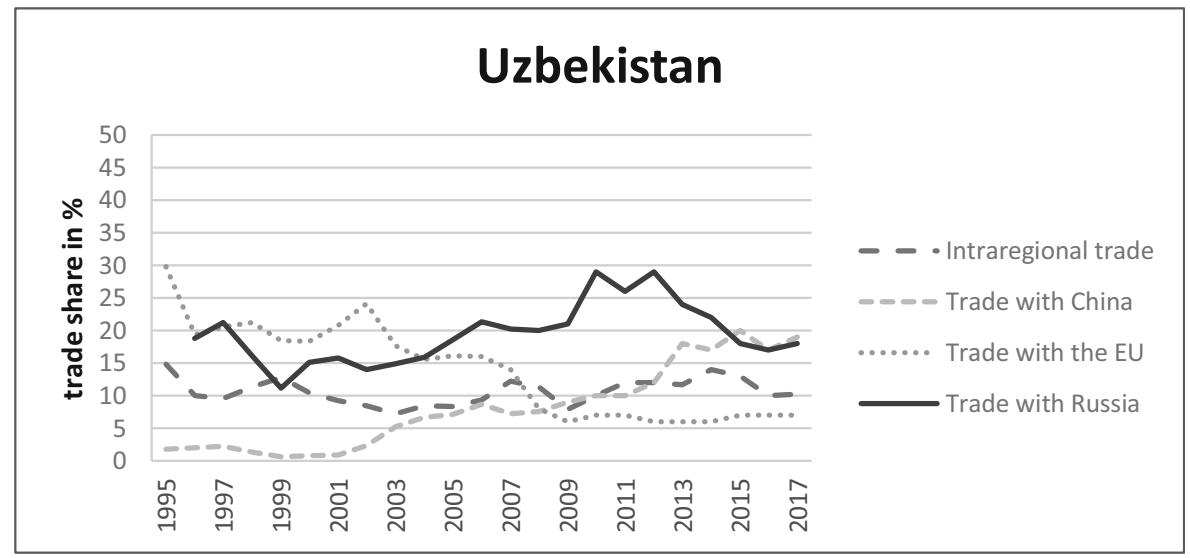

Fig. 4 Uzbekistan's International Trade. Total trade figures were obtained from UN Uzbekistan (data.mdgstat.uz/ru/data_finder/3332 and data.mdg-stat.uz/ru/data_finder/3332). Data for trade with China, Russia, Kazakhstan, Kyrgyzstan and Tajikistan in 2006-2017 were obtained from the official website of the Statistical Agency of Uzbekistan (https://stat.uz/ru). Data for Uzbekistan's trade in 1995-2005 and its trade with the EU were mirrored from UN Comtrade data of the respective trade partners 
This has been due to the acceleration of Chinese growth and to its increasing interest in Central Asian resources (Jenish 2015). Noteworthy, and in stark contrast with the Russian trade, the Chinese trade share did not decline in the 2008/9 crisis. Even though Russia still remains the most important trading partner for Kazakhstan (after the EU) and Tajikistan, China has already caught up in the case of Kyrgyzstan and Uzbekistan. The rising role of China in Central Asia leads to a growing competition for influenceor, in other words, a new 'Great Game' between China and Russia (Cooley 2012; Stronski and $\mathrm{Ng}$ 2018).

Up to here, the economic structure of Central Asia is surprisingly similar to that of Southeast Asia, where ASEAN constitutes one of the most advanced regional organisations in the developing world (Krapohl and Fink 2013; Krapohl 2017b). Intraregional trade within ASEAN is also relatively low (around $25 \%$ of member states international trade), and it was even lower in the past (ASEAN exists since 1967). Besides, the ASEAN member states also trade heavily with two extra-regional partners in the wider neighbourhood, namely with China and Japan. However, in contrast to the Central Asian countries, the ASEAN member states managed to keep their unity and were not torn apart by the power struggle between China and Japan. On the contrary, they were able to take advantage of the situation and ASEAN profits a lot from cooperation with China and Japan within the ASEAN+3 framework (e.g. the Chiang-Mai-Initiative; Krapohl 2015, 2017b). One reason for this is that there exists no regional power with extra-regional economic privileges within ASEAN. The four biggest economiesIndonesia, Malaysia, Singapore and Thailand-balance each other to some degree and none of them could achieve a unilateral advantage by cooperating on its own with either China or Japan. This marks an important difference to Central Asia, where Kazakhstan dominates the region in economic terms and is able to gain huge economic advantages by cooperating with Russia on its own.

Kazakhstan is Central Asia's regional power in economic terms, although its population $(18.5 \mathrm{mln})$ is less than that of Uzbekistan $(30 \mathrm{mln})$. Kazakhstan's economy is based on vast hydrocarbon and mineral reserves (foremost coal and uranium), but also developed a more advanced manufacturing sector, for instance in chemical industry (Guliev and Mekhdiev 2017; Sultanov 2014, p. 106). As a result of rising energy prices during the 2000s, Kazakhstan's GDP surged from a mere \$ 9 bln in the 1990 s to $\$ 160$ bln today $^{3}$ and is triple the size of the Uzbek economy ( $\$ 48$ bln) and more than 20 times larger than the Tajik or Kyrgyz economies (about $\$ 7$ bln each). ${ }^{4}$ As a result, the Russian-Chinese rivalry has been particularly pronounced in the case of Kazakhstan. Russia was the destination of up to $50 \%$ of Kazakh exports back in the 1990s. However, the relative importance of Kazakhstan's trade with Russia has been in constant decline since the 1990 s and fell down to $21 \%$ nowadays (Fig. 1). At the high of the financial crisis in 2008/9, when oil prices collapsed, trade with Russia even fell to a historical low of $10 \%$. At the same time, China caught up and raised its trade share from below $5 \%$ during the 1990 s to $13 \%$ today.

Oil forms the backbone of Kazakhstan's economy, and most of the Kazakh oil exports go to Europe. Thus, the share of Kazakhstan's trade with the EU is quite high (almost

\footnotetext{
${ }^{3}$ Notably, at a recent peak of oil prices in 2013, Kazakhstan's GDP reached 236 bln, but fell sharply in the coming three years, rising again only in 2017.

${ }^{4}$ GDP numbers are taken from the World Bank (data.worldbank.org/data-catalog/GDP-ranking-table) .
} 
40\%). However, the intense economic exchange with Europe does not reduce but rather contributes to Kazakhstan's dependency on Russia. Being a landlocked country and sharing a $7000 \mathrm{~km}$ border with Russia, Kazakhstan relies on Russian pipelines in order to export its oil to Europe (Jenish 2015). Among the most important pipelines are the Uzen-Atyrau-Samara pipeline, a northbound link to Russia's distribution system, and the Caspian Consortium pipeline, which brings Kazakh oil to the Russian Black Sea port of Novorossiysk (Eurasian Review 2012). About 85\% of Kazakh oil are exported to or via Russia. One of the few pipelines bypassing Russia is the Baku-Tbilisi-Ceyhan pipeline, which is however hard to reach (Kazakh oil is brought by tanker across the Caspian Sea) and transports only a very small share of Kazakh oil. The only connection to China is the Kazakhstan-China pipeline, running $2230 \mathrm{~km}$ from Kazakhstan's Caspian shore to Xinjiang in China, which was completed in 2005 and is currently being expanded. Oil exports to China are rapidly growing and make up $15 \%$ of the total volume. This share is likely to grow in the future, indicating an increasing Chinese influence in Central Asia (Kembayev 2018; Guliev and Mekhdiev 2017).

\section{The 'Second Great Game' and Russian interests in Central Asia}

Russia has been historically the pre-eminent power in Central Asia, having colonised the region during Tsarism in the nineteenth century and incorporated it into the Soviet Union after the Bolshevik revolution. In the twenty-first century, Russia's traditional dominance became increasingly challenged by China, so that Russia has been seeking to counterbalance a growing Chinese influence in the region. Moscow is keen on the region's natural resources and strives to control the routes of their transport and export (Melnykovska et al. 2012). To keep up with the supply obligations to Europe, Russian energy companies grew increasingly reliant on imports of Central Asian gas and oil (Cooley 2012, p. 65; Kuzmina 2010).

Among the five Central Asian countries, Kazakhstan is Russia's most important economic partner in the region. Apart from being a major supplier of oil, Kazakhstan is also an important crossroad territory for the transit of Turkmen and Uzbek gas, which goes to Russia and China (about 99 bln $\mathrm{m}^{3}$ per year). The export of Kazakhstan's own gas is negligible (13 bln $\mathrm{m}^{3}$ in 2017), but is rapidly growing, and before the end of 2017 it was entirely sold to Russia (BP 2018; Mazorenko 2014; Guliev and Mekhdiev 2017). ${ }^{5}$ Hydroenergy from Kyrgyzstan and Tajikistan also reaches Russia through the territory of Kazakhstan (Kuzmina 2010). Access to Kazakhstan's rich uranium reserves is also of primary interest to Russia as a major uranium manufacturer. Moreover, Russian companies, especially state monopolists, have substantial stakes in Kazakh oil fields, refineries, hydroelectric stations, pipelines and uranium enrichment plants (ibid).

Central Asia is furthermore a crucial region for Russia's national security interests (Jonson 2001). Among the main concerns are terrorism, drug trafficking, the fight against Islamic fundamentalism ${ }^{6}$ and regional separatism. Moscow has been trying to consolidate its military presence in the region by deploying military bases in

\footnotetext{
${ }^{5}$ In autumn 2017, after the construction of the Kazakhstan-China gas pipeline, a 1-year $5^{3}$ bln $\mathrm{m}^{3} \mathrm{deal}$ with China was put in place. In late 2018, it was extended by 5 years and $10 \mathrm{bln}^{3}$ (Erubaeva 2018).

${ }^{6}$ While the Central Asian states are secular, domestically Islam holds an important place (Spechler 2002). Due to poverty and political marginalisation, the region has become a growing source of foreign fighters, with up to 4000 people joining ISIS (International Crisis Group 2015).
} 
Kazakhstan, Kyrgyzstan and Tajikistan, and by binding these three countries into the Collective Security Treaty Organisation (CSTO) (Mesheryakov 2012; Bobokulov 2006). ${ }^{7}$ For Russia's security interests, Kazakhstan is again the most important country of Central Asia, and the two countries cooperate closely in military-industrial complexes, in atomic industry and in space. As a legacy from Soviet times, most Russian satellites are launched from the Kazakh space station Baikonur (Kuzmina 2010).

Since the collapse of the Soviet Union, Russia has always used regionalism as an instrument to keep or gain influence in the former Soviet republics. This began already with the establishment of the Commonwealth of Independent States (CIS) in 1991. However, the CIS proved to be rather dysfunctional, and economic integration could not prevail against the eagerness for independence in the former Soviet republics (Kubicek 1997). A new approach of economic integration was started in 2000 with the establishment of the Eurasian Economic Community (EurAsEC) by Belarus, Kazakhstan, Kyrgyzstan, Russia and Tajikistan. Uzbekistan joined EurAsEC in 2005 but left it again in $2008 .^{8}$ After the financial crisis of 2008, the three bigger EurAsEC member statesBelarus, Kazakhstan and Russia-formed a customs union, which was further institutionalised and renamed to Eurasian Economic Union (EAEU) in 2015 (Vinokurov 2018; Roberts and Moshes 2016). Armenia and Kyrgyzstan joined the EAEU within the same year, whereas Tajikistan's accession is still pending today. Unlike the CIS, the EAEU is underpinned by serious financial commitments and has nascent supranational institutions modelled upon the EU. Though an alliance with former Soviet republics has been always important to Russia, the strategic shift towards Eurasian integration became particularly pertinent since the deterioration of relations with the West in the wake of the annexation of Crimea (Trenin 2017; Krickovic and Bratersky 2016). Moreover, through the promotion of the EAEU, Russia has been seeking to counterbalance the rising Chinese influence in Central Asia (Kembayev 2018).

China's economy is growing rapidly and increasingly needs access to Central Asia's natural resources, in particular oil and gas but also metals and rare earths. China is also keen on getting access to Eurasian markets for its exports of cheap consumer goods, and views Central Asia as an important transit corridor for its exports to Europe (Peyrose and Raballand 2015; Melnykovska et al. 2012). Like Russia, China also has security interests in Central Asia, which neighbours its politically unstable province of Xinjiang (Rolland 2017; Bobokulov 2006). In order to fight political extremism and the simmering threat of Uyghur separatism in Xinjiang, China puts emphasis on the economic development of the province through intensified trade links with Central Asia (Raballand and Andresy 2007).

Despite being a potential competitor, China shares a common interest with Russia in preserving the political status quo in the region (rather than promoting democratisation), as well as keeping Western influence in Central Asia to the minimum (Stronski and Ng 2018). Therefore, China tried not to alienate Russia and pursue joint economic cooperation with Central Asia through the Shanghai Cooperation Organisation (SCO) - a regional organisation originating in the 1990s and comprising Russia, China and all Central Asian republics (except Turkmenistan) (Naarajärvi 2012; Yuan

\footnotetext{
${ }^{7}$ Originally, Uzbekistan was a member of the CSTO as well, but it withdrew its membership in 2012.

${ }^{8}$ The fifth Central Asian country, Turkmenistan, has followed a very isolationist policy since independence, and it has not joined any regional organisation at all. It is not even a full, but only an associate member of CIS.
} 
2010). However, fearing the expansion of Chinese influence in Central Asia, ${ }^{9}$ Russia vehemently opposed Chinese proposals such as a joint SCO free trade area and a development bank. China answered on this by launching the Asian Infrastructure Investment Bank without Russian involvement (Kembayev 2018; Gabuev 2017). More recently, China has been spearheading a gigantic infrastructure and development project titled 'Belt and Road' initiative (initially called 'One Belt, One Road'). It aims at reviving the ancient Silk Road by erecting a Eurasian transport-linked corridor for bringing Chinese exports to Europe via land roads in Central Asia (Dave and Kobayashi 2018; Rolland 2017). Among the 29 heads of state who attended the Belt and Road summit were the presidents of Kazakhstan, Kyrgyzstan and Uzbekistan (The Diplomat 2017). The presence of Vladimir Putin was perhaps symbolic for the ambivalent relationship between China and Russia as partners and competitors in Central Asia. Also indicative in this respect was the signing of a general agreement on 'trade and economic cooperation' between the Eurasian Economic Union and China in autumn 2017 (Eurasian Economic Commission 2017).

The increasing strength and influence of China threatens Russia's dominance and interests in the region. Remaining an important security provider, Russia loses its economic clout in Central Asia, with China increasingly becoming the economic driver of the region (Stronski and $\mathrm{Ng}$ 2018). In the framework of the Belt and Road initiative, China has pledged and started investing billions of dollars in Central Asian infrastructure, primarily roads and railways, in this way expanding overland routes to Europe for the export of Chinese goods. Chinese investment entails increasing indebtedness. For example, Kyrgyzstan owes $40 \%$ of its foreign debt to China. In Tajikistan, debt to China, the country's single largest creditor, accounts for $80 \%$ increase in Tajikistan's external debt over the past 10 years (Hurley et al. 2018).

In the context of the rising economic role of China, Russia wants to remain the gatekeeper for Central Asian trade with Europe and in particular to preserve its monopoly on the export of Central Asian hydrocarbons (Xin and Daleng 2015; Guangcheng 2015). Increased Central Asian exports of oil and gas to China could deprive Russia of transit fees and drive down the global oil price. At the same time, the economic downturn in Russia since 2014, exacerbated by Western sanctions and the continuously relatively low oil price, makes Russia less attractive as a market for Central Asian exports and as an origin of remittances, which went down considerably given the crisis and the depreciation of the rouble (IMF 2016). ${ }^{10}$ Additionally, the lack of pressure from China on political-military orientation, unlike from Russia, makes China an attractive partner for many Central Asian states. Chinese soft power influence is also on the rise, illustrated by the increasing numbers of Central Asian - primarily Kazakh — students obtaining their degrees in China. Still, most Central Asian students studying abroad go to Russia (Stronski and Ng 2018).

In the context of the 'Second Great Game', the Central Asian countries basically have two options. On the one hand, they can attempt to develop a unified regional stance in relation to extra-regional actors and to profit from the rivalry between China and Russia. This strategy has been successfully applied by the Southeast Asian countries, which use the

\footnotetext{
${ }^{9}$ While in the early 1990s the Russian and Chinese economies were about the same size, the speed of the Chinese economic growth and the resulting power imbalance raised concerns for Moscow (Kembayev 2018).

${ }^{10}$ As of 2017, remittances constituted about one-third of the Kyrgyz and Tajik GDP(data.worldbank.org/ indicator/BX.TRF.PWKR.CD.DT).
} 
regional organisation ASEAN in order to cooperate with the extra-regional powers China and Japan (Krapohl 2017b). On the other hand, the Central Asian countries can opt for closer bilateral relations with extra-regional actors at the expense of the genuine Central Asian integration. This happened for example in Southern Africa, where the regional power South Africa enjoyed privileged economic relations with the EU (Krapohl et al. 2014). Which of the two strategies prevails depends very much on Kazakhstan, which is a crucial player for regional integration in Central Asia, but which is also highly dependent on its economic relations with Russia.

\section{From the CAU to the EAEU}

There have been repeated efforts to establish a genuine Central Asian regional organisation in the last 25 years, but all of them have remained unsuccessful so far (Kubicek 1997; Pomfret 2009). We argue that the most important reason for the failure of Central Asian regionalism is the pull of extra-regional actors, foremost Russia, which has torn the region apart. As part of Russia's strategy within the 'Second Great Game', Eurasian integration provided economic and political gains for Kazakhstan that exceeded the possible gains of Central Asian regionalism by far. Thus, the regional power Kazakhstan opted for closer cooperation with Russia rather than cooperating with its regional neighbours. As a result, the Central Asian countries gave up their own attempts to create a regional organisation and some of them joined the Russian-led Eurasian integration project.

In the wake of the demise of the Soviet Union, the leaders of the five Central Asian countries met in 1992 to discuss options for regional cooperation. Turkmenistan's president Saparmurat Niyazov suggested to create a 'Confederation of Central Asian States' as an alternative to joining the Russian-lead CIS, but the other leader disagreed with Niyazov's proposal and opted for joining the CIS. A year later, it became clear that the CIS did not offer an effective framework to address the economic challenges of post-communist transformation in Central Asia. Following an initiative of the Uzbek president Islam Karimov, the Central Asian states decided to form their own regional organisation (Kubicek 1997). Turkmenistan refused to join, since president Niyazov remained suspicious of his colleagues after they refused his idea of the Confederation (Mesheryakov 2012). Being a neutral country according to the constitution and possessing abundant natural resource reserves, Turkmenistan did not participate in any regional integration initiatives since then (Yapic1 2018).

The integration process of the remaining four Central Asian states was driven by Kazakhstan and Uzbekistan, who had been traditionally competing for leadership in Central Asia. Integration was institutionalised in 1994, when Kazakhstan, Uzbekistan and Kyrgyzstan established the Central Asian Union (CAU). The Union was modelled upon the example of west-European integration and envisaged the creation of a single economic space with the goal of free movement of goods, capital, services and labour (Bobokulov 2006). Contrary to the CIS, the CAU had an economic rather than an ideological rationale and moved beyond joint declarations by establishing regional institutions such as the Intergovernmental Council, the Executive Committee and a bank designated to finance common projects. A further commitment to regional integration was signalled in 1995, when Uzbekistan worked out a regional development strategy until 2000 (Kubicek 1997). Tajikistan joined the regional organisation 
following the end of the civil war in 1998, and CAU was renamed as the Central Asian Economic Community (CAEC). Another 4 years later, the regional organisation once again changed its name to become the Central Asian Cooperation Organisation (CACO). The goals of CACO were broader than its predecessor organisations. Next to regional economic integration, the organisation addressed the new threats of terrorism and aimed to promote regional security (Mesheryakov 2012).

Despite ambitious goals, regionalism in Central Asian has not yielded desired results. CACO and its predecessor organisations have failed to develop an effective coordination of regional economic and trade policy. Instead, disagreements and protectionism persisted. For example, Kyrgyzstan's accession to the WTO in 1998 and the related liberalisation of its trade regime led to differences in trade policies and custom legislation among the members of CACO. When Kyrgyzstan became a major trading hub for the re-export of Chinese consumer goods, Kazakhstan and Uzbekistan took protectionist measures to shield their industries. Uzbekistan, which borders all other Central Asian states, has repeatedly closed its border with Kyrgyzstan and Tajikistan, which partly rely on transit through Uzbekistan in order to export their goods to Russia and Europe (Bohr 2004). Additionally, CACO suffered from disagreements between Kazakhstan and Uzbekistan, which were competing for regional leadership and had different policy interests. Whereas Kazakhstan was concerned about economic instability and separatism, Uzbekistan focused more on fighting religious extremism (Mesheryakov 2012). By 2003, CACO had become largely ineffective, and regional integration in Central Asia stalled.

Central Asian regionalism was captured by Russia and its Eurasian integration project. Russia always strove to become involved in Central Asian regionalism and became an observer to CAU and CAEC in the 1990s. When CACO was established in 2002, Russia made a decisive move and applied for membership in the organisation. The accession of Russia in 2004 meant de facto a fusion of CACO with the Russiacentred EurAsEC (Ministry of Foreign Affairs of the Russian Federation 2005), which had existed since 2000 and included the four Central Asian countries Kazakhstan, Kyrgyzstan, Tajikistan and Uzbekistan (Bobokulov 2006). The formal decision to abolish CACO in 2005 meant the end of genuinely Central Asian attempts at integration (Mesheryakov 2012). Today's EAEU, the successor organisation of EurAsEC, includes only Kazakhstan and Kyrgyzstan, but not the other Central Asian countries. Uzbekistan had already left EurAsEC in 2008, and Tajikistan has not yet been able to meet the preconditions of the EAEU's customs union. Thus, the external border of the EAEU's customs union runs through Central Asia and divides it into two parts.

In the context of a strong Russian pull, the economic priority of Central Asia's largest economy was a crucial factor in the failure of Central Asian regionalism. Sharing a border with Russia and being home to a large Russian minority, Kazakhstan has always seen Russia as part of any region that it belongs to and viewed Eurasian integration with Russia as a political priority (Kassenova 2012). Aside of oil exports to Europe, Russia is Kazakhstan's major trading partner so that economic gains of integrating with Russia by far outweigh gains from cooperation with Central Asian neighbours (trade figures discussed in 'Economic dependency of Central Asia' section corroborate that). The structural dependencies on the Russian pipeline system for the export of oil to Europe is another reason for seeking closer economic integration with Russia. Thus, Kazakhstan supported Eurasian integration together with Russia from the 
start. In fact, it was Kazakh president Nursultan Nazarbayev who aired his grand vision of a 'Eurasian Union' as early as 1994 (Konopelko 2018; Spechler 2002).

When choosing between Central Asian regionalism and extra-regional (i.e. Eurasian) economic privileges, Kazakhstan became a regional Rambo, which put its extraregional interests first. Russia did not reward regional cooperation in Central Asia systematically, but instead aimed to include Kazakhstan in the Eurasian integration project. Membership in the EAEU includes significant economic benefits for Central Asia's regional power. Kazakhstan gets access to the Russian market, gets disproportionally high investments and has access to the Russian pipeline network. Regional cooperation in Central Asia had not produced any of these benefits. Thus, when choosing between deepening the ties with its Central Asian neighbours and joining the EAEU, Kazakhstan opted for the latter, even when most of the Central Asian countries did not join the Russian-led organisation. Since the EAEU is a customs union, Kazakhstan's membership is not compatible with bilateral trade agreements and other forms of economic integration in the region, which effectively prevents Central Asian regionalism. As a result, the region has not been successful in establishing a common stance in relation to Russia and China. Instead of taking advantage of the rivalry between the two external powers, Central Asia is torn apart in the 'Second Great Game'.

\section{Conclusion}

The empirical analysis has demonstrated that the extra-regional interests of Kazakhstan and the external influence of Russia have led to the abandonment of regionalism in Central Asia. The failure of various regional organisations in Central Asia cannot conclusively be explained by blaming the lack of a regional hegemon, the weak regional identity or the authoritarian political systems of Kazakhstan, Kyrgyzstan, Tajikistan, Turkmenistan and Uzbekistan. The example of ASEAN demonstrates that regions can cooperate successfully and develop a regional identity despite lacking a regional hegemon and including authoritarian states. The Central Asian countries have not managed to cooperate regionally and to integrate their economies because they are torn apart in the 'Second Great Game'. Russia needs to balance a rapidly growing Chinese influence in Central Asia, and it used Eurasian integration as a strategic instrument to project power in the region. Thereby, EurAsEC and the EAEU have provided important economic (and political) gains for Kazakhstan, and regional cooperation with its Central Asian neighbours could never have been a substitute for that. As a result, Central Asia's largest economy put its extra-regional interests first, and Central Asian regionalism was doomed to fail. Instead of establishing a unified stance in the 'Second Great Game', Central Asia is fragmented and suffers from trade barriers, closed borders and political conflicts.

The crucial question for the academic field of comparative regionalism is, under which circumstances regional organisations constitute themselves successfully and when they are likely to fail. A comparison of Southeast Asia and Central Asia may be fruitful in this respect. Both regions consist of relatively small countries and constitute playing fields for the rivalry of larger external powers. However, whereas Central Asia has not been able to build up a unified position in relation to China and 
Russia, the ASEAN member states have established a stable regional organisation, which has become an important player in the wider neighbourhood and balances the influences of China and Japan (Stubbs 2014). This striking difference between the two regions can be due to several factors. The timing may have been much more favourable for ASEAN, which existed long before the rise of China and the resulting competition for regional hegemony with Japan. Besides, the Russian influence may be much more dominant in Central Asia than the Chinese or Japanese influence in Southeast Asia, because the Central Asian countries were de facto governed by Russia since Tsarist times. But all these are simple ad hoc explanations, and more research is necessary to get convincing answers.

European integration theories like or liberal intergovernmentalism (Moravcsik 1998), neofunctionalism (Haas 1961) or institutionalist approaches (Pollack 2003) cannot contribute much to the comparison of different developing regions, since they do not conceptualise the extra-regional dimension of regional integration. The European theories were developed on the example of an economically well-developed region, and they take intraregional economic interdependence for granted. However, intraregional economic exchange is much less important in developing regions, which are economically and politically much more dependent on extra-regional countries. This dependency leads to a huge influence of external actors on regionalism in developing regions - as the example of Russia's influence in Central Asia has shown. In order to bridge the gap between the two academic fields of comparative regionalism and EU studies (Söderbaum and Sbragia 2011; Warleigh-Lack and Rosamond 2010), we need to develop integration theories which systematically conceptualise the intraregional as well as the extra-regional effects of regionalism.

Open Access This article is distributed under the terms of the Creative Commons Attribution 4.0 International License (http://creativecommons.org/licenses/by/4.0/), which permits unrestricted use, distribution, and reproduction in any medium, provided you give appropriate credit to the original author(s) and the source, provide a link to the Creative Commons license, and indicate if changes were made.

\section{References}

Acharya A (2005) Do norms and identity matter? Community and power in Southeast Asia's regional order. Pac Rev 18, 95-118

Allison R (2004) Regionalism, regional structures and security management in Central Asia. Int Aff 80, 463483

Allison R (2008) Virtual regionalism, regional structures and regime security in Central Asia. Cent Asian Surv 27, 185-202

Bobokulov I (2006) Central Asia: is there an alternative to regional integration? Cent Asian Surv 25, 75-91

Bohr A (2004) Regionalism in Central Asia: new geopolitics, old regional order. Int Aff 80, 485-502

British Petroleum (BP) (2018) BP statistical review of world energy (www.bp. $\mathrm{com} / \mathrm{content} / \mathrm{dam} / \mathrm{bp} / \mathrm{en} /$ corporate/pdf/energy-economics/statistical-review/bp-stats-review-2018-fullreport.pdf)

Collins K (2009) Economic and security regionalism among patrimonial authoritarian regimes: the case of Central Asia. Eur Asia Stud 61, 249-281

Collins N, Bekenova K (2017) Fuelling the new great game: Kazakhstan, energy policy and the EU. Asia Europe Journal 15, 1-20

Cooley A (2012) Great games, local rules: the new great power contest in Central Asia. University Press, Oxford 
Dave B, Kobayashi Y (2018) China's silk road Economic Belt initiative in Central Asia: economic and security implications. Asia Europe Journal 16, 267-281

Doing Business (2019) Economy profile Kazakhstan. World Bank (www.doingbusiness. org/content/dam/doingBusiness/country/k/kazakhstan/KAZ.pdf). 21 Jan 2019

Erubaeva G (2018) Kazakhstan expands gas exports to China. Caspian News 30 November 2018 (caspiannews.com/news-detail/kazakhstan-expands-gas-exports-to-china-2018-11-29-42). 21 Jan 2019

Eurasian Economic Commission (2017) China and the EAEU declared the conclusion of negotiations on the agreement on trade and economic cooperation (www.eurasiancommission.org/en/nae/news/Pages/2-102017-5.aspx). 21 Jan 2019

Eurasian Review (2012) Kazakhstan energy profile: second largest oil reserves among former Soviet Republics (www.eurasiareview.com/06052017-kazakhstan-energy-profile-second-largest-oil-reservesamong-former-soviet-republics-analysis-2). 21 Jan 2019

Frankopan P (2016) The silk roads: a new history of the world. Knopf, New York

Gabuev A (2017) Bigger, not better: Russia makes the SCO a useless Club. Carnegie Moscow Center, Moscow

Gleason G (2001) Inter-state cooperation in Central Asia from the CIS to the Shanghai forum. Eur Asia Stud 53, 1077-1095

Guangcheng X (2015) The strategic interests of China and Russia in Central Asia. In: Denoon D (ed) China, the United States and the future of Central Asia. New York University Press, New York

Guliev I, Mekhdiev E (2017) The role of fuel and energy sector in the Eurasian economic community integration process. Int J Energy Econ Policy 7, 72-75

Haas EB (1961) International integration: the European and the universal process. Int Organ 15, 266-292

Haftel YZ (2007) Designing for peace: regional integration arrangements, institutional variation, and militarized interstate disputes. Int Organ 61, 217-237

Holzinger K (2003) Common goods, matrix games and institutional response. Eur J Int Relat 9, 173-212

Hurley J, Morris S, Portelance G (2018) Examining the debt implications of the belt and road initiative from the policy perspective. Center for Global Development Policy Paper 121 (www.cgdev. org/sites/default/files/examining-debt-implications-belt-and-road-initiative-policy-perspective.pdf). 21 Jan 2019

IMF (International Monetary Fund) (2016) Regional Economic Outlook: Caucasus and Central Asia (www. imf.org/ /media/Files/Publications/REO/MCD-CCA/2016/October/cca1016.ashx). 21 Jan 2019

International Crisis Group (2015) Syria calling: radicalisation in Central Asia. Europe and Central Asia Briefing 72 (www.crisisgroup.org/europe-central-asia/central-asia/syria-calling-radicalisation-centralasia). 21 Jan 2019

International Crisis Group (2017) Central Asia's silk road rivalries. Europe and Central Asia Report 245 (www.crisisgroup.org/europe-central-asia/central-asia/245-central-asias-silk-road-rivalries). 21 Jan 2019

Jenish N (2015) Walls and windmills: economic development in Central Asia. In: Denoon D (ed) China, the United States and the future of Central Asia. New York University Press, New York, 20-74

Jonson L (2001) Russia and Central Asia. In: Allison R (ed) Central Asian security. Brookings Institution, Washington, 95-126

Kassenova N (2012) Kazakhstan and Eurasian economic integration: quick start, mixed results and uncertain future. Russie Nei Reports 14. Institut Francais des Relations Internationales (IFRI), Paris

Kembayev Z (2018) Implementing the silk road Economic Belt: from the Shanghai cooperation organisation to the silk road union? Asia Europe Journal 16, 37-50

Konopelko A (2018) Eurasian economic union: a challenge for EU policy towards Kazakhstan. Asia Europe Journal 16, 1-17

Krapohl S (2015) Financial crises as catalysts for regional cooperation? Chances and obstacles for financial integration in ASEAN+3, MERCOSUR and the Eurozone. Contemp Polit 21, 161-178

Krapohl S (2017a) Two logics of regional integration and the games regional actors play. In: Krapohl S (ed) Regional integration in the global south: the external influence on economic cooperation in ASEAN, MERCOSUR and SADC. Palgrave, Basingstoke, 33-62

Krapohl S (2017b) ASEAN: extra-regional cooperation triggers regional integration. In: Krapohl S (ed) Regional integration in the global south: the external influence on economic cooperation in ASEAN, MERCOSUR and SADC. Palgrave, Basingstoke, 115-146

Krapohl S, Fink S (2013) Different paths of regional integration: trade networks and regional institutionbuilding in Europe, Southeast Asia and Southern Africa. J Common Mark Stud 51, 472-488

Krapohl S, Meissner KL, Muntschick J (2014) Regional powers as leaders or rambos of regional integration? Unilateral actions of Brazil and South Africa and their negative effects on MERCOSUR and SADC. J Common Mark Stud 52, 879-895 
Krickovic A, Bratersky M (2016) Benevolent hegemon, neighborhood bully, or regional security provider? Russia's efforts to promote regional integration after the 2013-2014 Ukraine crisis. Eurasian Geogr Econ 57, 180-202

Kubicek Paul (1997): 'Regionalism, nationalism and Realpolitik in Central Asia', in: Europe-Asia Studies, 49: 4, 637-655

Kuzmina N (2010) Ekonomicheskiye interesy Rossii v Zentralnoy Azii Zentralnaya Aziya: Aktualnye Akzenty Mezhdunarodnogo Sotrudnichestva. MGIMO University, Moscow, 23-39

Lake DA (2009) Regional hierarchy: authority and local international order. Rev Int Stud 35, 35-58

Mansfield ED, Milner HV (1999) The new wave of regionalism. Int Organ 53, 589-627

Mattli W (1999) The logic of regional integration: Europe and beyond. Cambridge University Press, Cambridge

Mazorenko D (2014) Skolko Kazakhstan zarabatyvaet na transite gaza i nefti? Vlast 10 September 2014 (vlast. kz/jekonomika/skolko_kazahstan_zarabatyvaet na_tranzite_gaza_i_nefti-7306.html)

Melnykovska I, Plamper H, Schweickert R (2012) Do Russia and China promote autocracy in Central Asia? Asia Europe Journal 10, 75-89

Mesheryakov K (2012) Integracionniye Prozessy na Postsovetskom Prostranstve i Uchastiye v Nikh Rossii. Skiphia Print, St Petersburg

Ministry of Foreign Affairs of the Russian Federation (2005) On the Summit of CACO, Saint Petersburg, 6 October 2005 (www.mid.ru/central-noaziatskoe-soobsestvo-cas-/-/asset_publisher/0vP3hQoCPRg5 /content/id/ 425166)

Moravcsik A (1998) The choice for Europe: social purpose and state power from Messina to Maastricht. Cornell University Press, Ithaca

Muntschick J (2017) SADC: extra-regional trade relations constrain deeper market integration. In: Krapohl S (ed) Regional Integration in the Global South: External Influence on Economic Cooperation in ASEAN, MERCOSUR and SADC. Palgrave, Basingstoke, 179-208

Myant M, Drahokoupil J (2008) International integration and the structure of exports in central Asian republics. Eurasian Geogr Econ 49, 604-622

Naarajärvi T (2012) China, Russia and the Shanghai cooperation organisation: blessing or curse for new regionalism in Central Asia? Asia Europe Journal 10, 113-126

Peyrose S, Raballand G (2015) Central Asia: the new silk road Initiative's questionable economic rationality. Eurasian Geogr Econ 56, 405-420

Pollack MA (2003) The engines of European integration: delegation, agency, and agenda-setting in the EU. Oxford University Press, Oxford

Pomfret R (2009) Regional integration in Central Asia. Econ Chang Restruct 42, 47-68

Raballand G, Andresy A (2007) Why should trade between Central Asia and China continue to expand? Asia Europe Journal 5, 235-252

Roberts SP, Moshes A (2016) The Eurasian economic union: a case of reproductive integration? Post-Sov Aff $32,542-565$

Rolland N (2017) China's 'Belt and road initiative': underwhelming or game-changer? Wash Q 40, 127-142

Russel M (2019) Connectivity in Central Asia: reconnecting the silk road. European parliamentary research service briefing (www.europarl.europa.eu/RegData/etudes/BRIE/2019/637891/EPRS_BRI(2019 637891 EN.pdf)

Samokhvalov V (2016) The new Eurasia: post-soviet space between Russia, Europe and China. Eur Polit Soc $17,82-96$

Schirm SA (2002) Globalization and the new regionalism: global markets, domestic politics and regional cooperation. Wiley, Cambridge

Sheives K (2006) China turns west: Beijing's contemporary strategy towards Central Asia. Pac Aff 79, 205224

Söderbaum F, Sbragia A (2011) EU studies and the 'new regionalism': what can be gained from dialogue? J Eur Integr 32, 563-582

Spechler M (2002) Regional cooperation in Central Asia. Probl of Post-Communism 49, 42-47

Stein AA (1982) Coordination and collaboration: regimes in an anarchic world. Int Organ 36, 299-324

Stronski P, Ng N (2018) Cooperation and competition: Russia and China in Central Asia, the Russian Far East, and the Arctic. Carnegie Endowment for International Peace (carnegieendowment.org/2018/02/28 /cooperation-and-competition-russia-and-china-in-central-asia-russian-far-east-and-arctic-pub-75673) . 21 Jan 2019

Stubbs R (2014) ASEAN's leadership in east Asian region-building: strength in weakness. Pac Rev 27, 523541 
Sultanov B (2014) Kazakhstan and Eurasian integration. In: Dutkiewicz P, Sakwa R (eds) Eurasian Integration-The View Within. Palgrave, Basingstoke, 97-110

The Diplomat (2017) Belt and road attendees list (thediplomat.com/2017/05/belt-and-road-attendees-list/). 21 Jan 2019

Trenin D (2017) Russia's evolving grand Eurasia strategy: will it work? Carnegie Moscow Center, Moscow

Vinokurov E (2018) Introduction to the Eurasian economic union. Palgrave, Basingstoke

Von Hauff L (2018) Towards a new quality of cooperation? The EU, China, and Central Asian security in a multipolar age. Asia Europe Journal (online first)

Wang W (2014) The effect of regional integration in Central Asia. Emerg Mark Financ Trade 50, 219-232

Warleigh-Lack A, Rosamond B (2010) Across the EU-studies-new regionalism frontier: invitation to a dialogue. J Common Mark Stud 48, 993-1013

Xin L, Daleng X (2015) Chinese and Russian economic interests in Central Asia: comparative analysis. In: Denoon D (ed) China, The United States and The Future of Central Asia. New York University Press, New York, 130-153

Yapic1 U (2018) From positive neutrality to silk road activism? The continuities and changes in Turkmenistan's foreign policy. J Balkan Near East Stud 20, 293-310

Yuan J-D (2010) China's role in establishing and building the Shanghai cooperation organization (SCO). J Contemp China 19, 855-869

Zürn M (1993) Problematic social situations and international institutions: on the use of game theory in international politics. In: Pfetsch F (ed) International Relations and Pan-Europe: Theoretical Approaches and Empirical Findings. Lit Verlag, Münster, 63-84

Publisher's note Springer Nature remains neutral with regard to jurisdictional claims in published maps and institutional affiliations. 